\title{
Management of changes in the insurance industry in the conditions of climate crisis
}

\author{
Nelia Nagaichuk*, Olena Shabanova, Natalia Tretiak, Anatoliy Marenych, and Hanna Chepeliuk \\ Cherkasy educational-scientific institute of the Banking University, Cherkasy, 18028 Ukraine
}

\begin{abstract}
The insurance industry is rather effective in overcoming consequences of natural disasters. Insurance companies play a key role in financing natural disasters consequences, at the same time they sustain record losses and are in difficult financial conditions. Taking into account the above said, the issues of management of insurers risks is up-today and is connected with climate change. In article the content of "climate risk" as risk is specified, the emergence of which is caused by human activity, which leads to pollution, resulting from industrial activity and other sources that greenhouse gases (carbon dioxide) which are capable to absorb a range of infrared radiation generate and, as a result, predetermine warming of the global atmosphere that brings to change of structure of the world atmosphere and adds natural climate instability during the certain periods of time. The most destructive dangers threatening to mankind owing to global warming are systematized. Types of risks and their sphere of manifestation in Ukraine are outlined. The directions of adaptation of the insurance industry to changes, caused by climatic crisis are defined. Due to results of the research, the theoretical generalization and author's solutions of a scientific task are offered, which appear in the development of scientific and methodical approaches and justification of practical recommendations about modernization of activity of insurance companies and reinsurers in the conditions of risks, generated by global climate changes. Scientific novelty of the research: specifying the role of the insurance industry regarding the prevention of risks connected with global warming.
\end{abstract}

\section{Introduction}

The climate change process, mainly because of its influence on the environment, has destructive consequences which mankind faces now and will face in the future. Risks of natural disasters and climate change draw the main attention of world politicians and mass media now.

The climate change does rather a significant effect on the activity of insurers as new insurance risks appear, the sizes of the insured losses are growing owing to natural disasters that forces insurers to raise insurance rates. As the growth of intensity of extreme weather conditions is observed, the risk of harming of property and human lives is also increasing. In this regard for insurance companies the climate change - is rather a threat, than an opportunity for business development. Therefore insurance companies need to adapt to climate change, predicting how climate changes and their consequences will affect the insurance risks of their clients. For this purpose, it is necessary to estimate risk and to revise some corporate procedures (pricing, conditions of the signing of the contracts, etc.) taking into the consideration the tendency of the insurer to risk, depending on a field of activity, geographic location, the existence of opportunities and conditions for business and other factors. Many initiatives at the international and national levels are devoted to the solution of this task.
The aim of the research is the definition of the directions of adaptation of insurance companies to changes in a profile of the risks caused by climatic crisis.

\section{Results}

The term "climate" occurs from Greece and means area and in a common understanding connected with weather conditions of the region that are recorded for a long time. The climate characteristics are average quantity of annual rainfall (rain, snow, etc.), the maximum and minimum temperatures throughout all season, the number of the sundial, humidity level, frequency of extreme weather conditions, etc. Thus, climate is understood as statistics of weather conditions within a decade and more [1].

The concept of "climatic changes" is used for the characteristic of global changes in the climate, long-term changes of average planetary temperature or is used for demonstration of changes of weather conditions, which occur at the local and regional levels. Thus, climatic changes are large-scale long-term changes in weather conditions of the planet or its average temperatures [1]. Such changes are straight lines or the mediated consequences of human activity that lead to change of structure of the world atmosphere and add natural inconstancy of climate during certain periods of time. In the context of the definition given above, human activity

\footnotetext{
* Corresponding author: nagaichuk n@ukr.net
} 
is pollution which results from industrial activity and other sources that generate greenhouse gases (carbon dioxide) which are capable to absorb a range of infrared radiation generate and, as a result, predetermine warming of the global atmosphere.

Nowadays, the negative consequences of climate change consider a threat to security, putting it on one step with the terrorism threats. Researchers insist on necessity to refuse from the term "climatic change" and thus to continue supporting the opinion that it is a passive problem that does not demand urgent intervention. However, it is necessary to use the concept "climate crisis" that gives the understanding that it is not a problem of the long-term future, but danger which needs to be prevented already today. And the Swedish activist Greta Tunberg, called the changes happening in a climate of the planet - climate ruin or climate emergency situation.

The term "climatic changes" was entered into scientific and political use by the geophysicist Wallace S. Broker, having published in 1975 the first thorough work about global warming and if more precisely, then heatings, under the name "climate changes: or are we on the verge of pronounced global warming?" and rather long time, the term" global warming "was widely used. However, in the next decades the description of increase in global temperature, changes of weather and atmospheric conditions were changed to the more neutral term "climate change" which allowed to soften perceptions of the existing problem, connected with global "heating". Use of the term "global warming" is more accurate from the technical point of view as it characterizes changes in the power balance of the planet. Such an approach allows us to speak about risk, but not about uncertainty.

Climate changes should be perceived as the emergency situation and terms which are used for its designation have to reflect the degree of sharpness (urgency). According to scientists' research, the mankind has about 10-12 years to prevent climatic crisis. For this reason, they consider that it is correct to speak about risks of safety, and climate change should not be considered as mainly external. Climate changes reveal the risks inherent in modern society that cause dangers [1]. Only such understanding of the essence of climate risk reflects cause and effect, understanding of which allows to react adequately" to the multifaceted characteristics of climate risks, connected to the safety of people and societies" [2].

In table 1 is given characteristic of agreements in the sphere of global heating which Ukraine has joined.

Thus, we can observe a certain evolution in the understanding of problems, related to climate change. If in "The Rio Convention" generally questions were linked to ecology, then the Kyoto Protocol contains obligations for the countries on the search of mechanisms of reduction and stabilization of greenhouse gases. However, the mechanisms found were commercialized - the countries with low economic development began to trade with its greenhouse quotas, therefore such an approach did not help to achieve goals - decrease of the concentration of greenhouse gases.

Orientation to the development of "green" power was another moment of the Kyoto Protocol. In many countries of the world including Ukraine, businessmen that developed "green" power received extraordinary preferences from the governments. As materials of the World Meteorological Organization (WMO) showed preferential development of "green" power did not give tangible results in the fight against greenhouse emissions [3]. Therefore, according to the Parisian agreement until 2020 the long-term plans had to be developed, in order to provide concrete steps in the sphere of decrease of greenhouse gases in emissions and prevention of global "heating".

Table 1. Agreements in the sphere of global heating which Ukraine has joined.

\begin{tabular}{|c|c|l|}
\hline Agreement & $\begin{array}{c}\text { Date of } \\
\text { signing }\end{array}$ & \multicolumn{1}{|c|}{ Content } \\
\hline $\begin{array}{c}\text { The Framework } \\
\text { Convention on } \\
\text { Climate Change- } \\
\text { "Rio Convention" } \\
9^{\text {th }} \text { of May } \\
1992, \text { New } \\
\text { York }\end{array}$ & $\begin{array}{l}\text { The agreement between the co- } \\
\text { untries that provides preventi- } \\
\text { on of dangerous anthropogenic } \\
\text { impact on climate of Earth. } \\
\text { Emphasis on the conservation } \\
\text { of biodiversity and steady use } \\
\text { of its components. }\end{array}$ \\
\hline $\begin{array}{c}\text { The Kyoto } \\
\text { Protocol is the } \\
\text { annex to "Rio } \\
\text { Convention" }\end{array}$ & $\begin{array}{c}11^{\text {th }} \text { of } \\
\text { December } \\
1997, \\
\text { Kyoto }\end{array}$ & $\begin{array}{l}\text { The participating countries ag- } \\
\text { reed during 2008-2012 to redu- } \\
\text { ce and stabilize the level of } \\
\text { emissions of greenhouse gases } \\
\text { to the level of 1990 }\end{array}$ \\
\hline $\begin{array}{c}\text { The Parisian } \\
\text { agreement - the } \\
\text { additional } \\
\text { document to "Rio } \\
\text { Convention" }\end{array}$ & $\begin{array}{c}12^{\text {th }} \text { of } \\
\text { December } \\
2015, \text { Paris }\end{array}$ & $\begin{array}{l}\text { Commitments as for reduction } \\
\text { of emissions of greenhouse ga- } \\
\text { ses undertake all countries ir- } \\
\text { respective of the level of } \\
\text { economic development. }\end{array}$ \\
\hline
\end{tabular}

The Conference on climate (COP25) was held during two weeks of December 2019 in Madrid (Spain). The UN Secretary-General Antonio Guterres, in the report, emphasized that the mankind can move in two ways: "As sleepwalker and to pass a non-return point, thereby to put under the risk health and safety of each and one person of the planet" and" by hope" which provides efforts in the direction of controlling increase in global temperature within $1.5^{\circ} \mathrm{C}$ and to the middle of the century to reduce emissions of greenhouse gases to zero, having refused use of fossil fuel [4]. The secretary-general emphasized that the main subject of the World Economic Forum in Davos in 2020 will be the problem of strengthening of climatic crisis and loss of biodiversity, as temperature records and natural disasters became the main manifestations of global warming in 2019.

The relevance of this perspective is shown also in the report of the World Economic Forum (WEF) prepared. According to data, the presented in the document, more than $50 \%$ of world GDP is dependent on state of environment that makes about $\$ 44$ trillion in absolute figures [5]. The experts call industries such as constructions - \$4 trillion, agriculture - \$2.5 trillion, production of food and drinks $-\$ 1.4$ trillion are the most dependent on climate changes. As their activity or depends on resources that are received from the environment or are based on services that are received from ecosystems - clear water, fertile soils, pollinations and stable climate. In case of impossibility of receiving by 
these industries from the environment raw materials and services, they experience enormous losses. So, according to the data of the report of WEF (Global Risk Report 2020), the most dependent on climate industries produce $15 \%$ of world GDP - about $\$ 13$ trillion and 37\% which are moderately dependent makes $\$ 31$ trillion.

Also WEF submitted the list of 10 main dangers which may threaten humanity in 2020, nine of which are connected with climate change. These risks were estimated by two criteria - the most potentially destructive and the most probable (table 2).

Table 2. The most likely and most devastating threats to humanity.

\begin{tabular}{|c|c|}
\hline Most likely & $\begin{array}{c}\text { The most potentially } \\
\text { destructive }\end{array}$ \\
\hline Extreme weather & $\begin{array}{c}\text { Climate change } \\
\text { inactivity }\end{array}$ \\
\hline $\begin{array}{c}\text { Inactivity is in connection with the } \\
\text { change of climate }\end{array}$ & $\begin{array}{c}\text { Weapons of mass } \\
\text { destruction }\end{array}$ \\
\hline Natural disasters & Loss of a biodiversity \\
\hline Loss of biovariety & Natural disasters \\
\hline $\begin{array}{c}\text { Environmental disasters are } \\
\text { provoked by the humankind }\end{array}$ & Water crisis \\
\hline
\end{tabular}

Source: powered by [6].

All of this is a confirmation that climate changes threaten social and economic stability and need a search of ways of its minimization and elimination. The formation of strong economy and creation of social stability is a question of global interest - and the steady future has to become the collective choice.

Taking into the consideration specific nature of activity, insurers especially understand that warming of climate for more than 2 degrees can lead to extremely high risks of impact on the environment and impossibility to provide customers with available insurance products.

Based on results of ranging potential threats behind the probability and the consequences presented by Willis Towers Watson's Thinking Ahead Institute, it is identified the three of new risks for insurers, namely climate risk, the Cyber risk and political risk.

Climate risk is a degree of probability of adverse weather during the certain period of time [7]. Naturally climatic and social aspects of risks are marked out in the system of global climatic changes [8]. Examples of realization of the risks generated by climatic changes are represented in the table 3 .

Nowadays in Ukraine climate risks are manifested in the spheres of agriculture, energy and health care and also influence on the quality of water sources of country (table 4).

As Ukraine has agro-industrial specialization, the most notable influence of climate risks will be on agricultural production. According to experts conclusions, within the next $10-15$ years our country will face threat of $25 \%$ loss of productivity of soils that will turn out to be consequence of temperature change and an amount of precipitation that in total with exhaustion of soils and escalation of extreme weather conditions will lead to a critical situation [11].
Table 3. Type of risk and its manifestations.

\begin{tabular}{|c|c|c|}
\hline & Type & f risk \\
\hline & social & socio-political \\
\hline . & $\begin{array}{l}\text { increase of death rate from } \\
\text { strengthening of heat-waves }\end{array}$ & $\begin{array}{c}\text { increase of migratory } \\
\text { streams of population } \\
\text { (appearance of ecological or } \\
\text { climatic refugees) }\end{array}$ \\
\hline 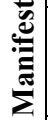 & $\begin{array}{l}\text { expansion of a zone of } \\
\text { inoculable diseases }\end{array}$ & $\begin{array}{c}\text { humanitarian problems } \\
\text { (deficiency of food, } \\
\text { drinking water) }\end{array}$ \\
\hline & $\begin{array}{l}\text { increase in the health risk } \\
\text { (increase in incidence and } \\
\text { death) some social groups of } \\
\text { the population }\end{array}$ & \\
\hline
\end{tabular}

Growth of frequency and consequences of the natural disasters caused by climatic changes threaten life and health of humanity their property safety, worsen food security, so has a negative effect on global economic development. All this demands existence of adaptable mechanisms which make society steady to the consequences caused by climate change. Adaptation to climate changes is an increase of ability to be restored from consequences of catastrophic events, that is decrease in vulnerability and increase in financial and physical resistance to disasters. Insurance mechanisms are suitable in both aspects of adaptation to climatic changes.

Their realization occurs on two vectors:

1) through formation of insurance funds proving receipt of financial resources for payments of compensations to citizens and on restoration of infrastructure after the disaster insured event happened. Without properly organized insurance protection a burden of payment of losses lays down on certain citizens, the governments or the organizations assisting and it significantly presses on budgets of the state that finally leads to economic and social difficulties for injured;

2) by informing society on the nature of the risks generated by climate change and assistance of realization of actions for improvement of protection against the disasters caused by climatic changes. Experience of insurers becomes useful at risk assessment of approach to a concrete event and its consequences or to consider during selection ways and sites.

Effects of climate change on world economy are presented on figure 1 .

The insurance market plays a huge role, helping to soften consequences of natural disasters and to react to them that demands complete survey of the new risks which are on the agenda for insurance companies.

The countries that have broad coverage of insurance protection recover from consequences of natural disasters much quicker. The governments of economically developed countries understand a role and benefits of insurance upon natural disasters, though, so far a large amount of risks remains not covered by insurance, so there is "a gap in protection".

Use of insurance mechanisms in the conditions of climate change is the transition from climatic crisis to management of climate risks providing conditions of social and economic stability of society. 
Table 4. Spheres of manifestation and consequence of climate risks in Ukraine.

\begin{tabular}{|c|c|c|c|c|}
\hline & & phere of $n$ & nanifestation 0 & f climate risk \\
\hline & \begin{tabular}{|c} 
agricul- \\
ture
\end{tabular} & $\begin{array}{c}\text { water re- } \\
\text { sources }\end{array}$ & energy sphere & healthcare \\
\hline & $\begin{array}{l}\text { - losses } \\
\text { of a har- } \\
\text { vest; } \\
\text { - changes } \\
\text { of pe- } \\
\text { riods of } \\
\text { ripening } \\
\text { of agri- } \\
\text { cultural } \\
\text { cultures; } \\
\text { - an in- } \\
\text { crease of } \\
\text { their vul- } \\
\text { nerability } \\
\text { is to the } \\
\text { wre- } \\
\text { ckers; } \\
\text { - resour- } \\
\text { ce deple- } \\
\text { tion: los- } \\
\text { ses of the } \\
\text { fertility } \\
\text { of the } \\
\text { soil, de- } \\
\text { sertifica- } \\
\text { tion, ero- } \\
\text { sion etc. }\end{array}$ & $\begin{array}{l}\text { - violati- } \\
\text { on of the } \\
\text { hydrody- } \\
\text { namic } \\
\text { mode and } \\
\text { water ba- } \\
\text { lance of } \\
\text { the rivers; } \\
\text { - degrada- } \\
\text { tion of } \\
\text { water re- } \\
\text { sources, } \\
\text { related to } \\
\text { the chan- } \\
\text { ges of the } \\
\text { water mo-- } \\
\text { de, exha- } \\
\text { ustion, } \\
\text { contami- } \\
\text { nation } \\
\text { through } \\
\text { the sur- } \\
\text { plus loa- } \\
\text { ding. }\end{array}$ & $\begin{array}{l}\text { an increase of } \\
\text { demand on } \\
\text { electric power } \\
\text { during a sum- } \\
\text { mer heat; } \\
\text { complication } \\
\text { of functioning } \\
\text { of objects of } \\
\text { hydro- } \\
\text { energetics } \\
\text { through chan- } \\
\text { ges in cha- } \\
\text { racter of pre- } \\
\text { cipitations } \\
\text { and river } \\
\text { flow; } \\
\text { negative con- } \\
\text { sequences are } \\
\text { from the ext- } \\
\text { reme weather } \\
\text { phenomena; }\end{array}$ & $\begin{array}{l}\text { - increase in the num- } \\
\text { ber of victims of heat- } \\
\text { stroke's; } \\
\text { - worsening of health } \\
\text { of urban population } \\
\text { through superficial } \\
\text { contamination and } \\
\text { changes in an ozone } \\
\text { layer; } \\
\text { - increase of level of } \\
\text { death rate as a result } \\
\text { of cardiovascular di- } \\
\text { seases; } \\
\text { - increase of allergic } \\
\text { and asthmatic } \\
\text { diseases of drying out } \\
\text { of peat bogs in the } \\
\text { north of Ukraine and } \\
\text { Polesye that will } \\
\text { entail frequent fires; } \\
\text { - increase of intestinal } \\
\text { and infectious } \\
\text { diseases as a result of } \\
\text { worsening of quality } \\
\text { of drinking water; } \\
\text { - allergic reactions are } \\
\text { as a result of bites of } \\
\text { insects from Africa, } \\
\text { Near East and Medi- } \\
\text { terranean, and also } \\
\text { poisonous spiders } \\
\text { east; } \\
\text { - appearance of mala- } \\
\text { ria, fever of Riphtali } \\
\text { and other infectious } \\
\text { diseases; } \\
\text { - growth of quantity } \\
\text { of cases of diseases of } \\
\text { tick-borne borreliosis } \\
\text { (Lyme's disease) and } \\
\text { tick-borne encephali- } \\
\text { tis owing to increase } \\
\text { the number of pin- } \\
\text { cers; } \\
\text { - emergence atypical } \\
\text { earlier for Ukraine } \\
\text { and increase in quan- } \\
\text { tity of cases of alrea- } \\
\text { dy known infectious } \\
\text { diseases (HIV / } \\
\text { AIDS, Hemorrhagic } \\
\text { fever with renal synd- } \\
\text { rome, hepatitis C, aty- } \\
\text { pical pneumonia, } \\
\text { COVID-19 and } \\
\text { others) owing to inc- } \\
\text { rease in a flow of cli- } \\
\text { matic refugees. } \\
\end{array}$ \\
\hline
\end{tabular}

Source: powered by $[9,10,11,12]$

As a result of adverse effects of climate change, insurance business faces large-scale insurance losses. On the agenda there are questions of risk management of insurers, relate to climate change - all potential risks which can influence on the companies, regions, the countries or mankind in general. In the long term, in the absence of activities for adaptation to consequences of global warming insurers will be forced to raise the prices and for millions of people insurance protection may become inaccessible. For the purpose of prevention of such situation it is necessary to study physical risks and to develop adaptation measures for minimization or neutralization of their action.

The growing frequency and weight of natural disasters that is a consequence of climatic changes, in the shortterm period can lead to increase in receipts of awards, but in the long term can be financially excessive for insurers. In this regard experts determine the major factors limiting desire of insurers to take risks which are connected to the climate change on insurance:

- almost unpredictable consequences of global warming;

- increase in oceans level;

- increase of intensity of natural disasters.

In work "Insurance for climatic adaptation: opportunities and restrictions" [13], presented to the Global commission on questions of adaptation, authors are formulated recommendations to receive the maximum benefit from insurance in the course of climatic adaptation:

1) Invest in models with the open code which provide the long-term review of climate risk and the reference to insurance decisions.

2) Development of united politics, so to implement models of climate risk in the basis for national strategy of adaptation.

3) To develop coherent regulations and standards of climatic adaptation in different countries.

4) To promote an innovation in the sphere of insurance which can react to the changing climate risk.

5) To strengthen dialogue between insurers and developers of policy around "To make it better".

6) Convergent programs of insurance, humanitarian aid and development.

7) Promoting and investments of money in literacy of society [13].

Based on the results, presented in Global Risk Report 2020 , the main threats to security of mankind are climate crisis, reduction of biological diversity and record extinctions of different types of plant and animal. Owing to human activity $83 \%$ of all wild mammals and a half of plants already disappeared from the planet that threatens nutrition and health systems.

About $78 \%$ of the experts participating in polls by preparation of the report noticed that they expect a strengthening of economic confrontation and internal political split in the certain states in 2020 that will have catastrophic consequences, especially for the environment [5].

Top 5 the largest risks which threaten to the planet in the next ten years are related to ecology among which: extreme weather conditions which lead to death of people and loss of property; a policy failure mitigation of the consequences of climatic changes from the governments and the large companies; an anthropogenic threat to the 
environment and environmental crimes; loss of a biodiversity and destruction of ecosystems; big natural disasters like earthquakes, a tsunami, eruptions of volcanoes and geomagnetic storms.

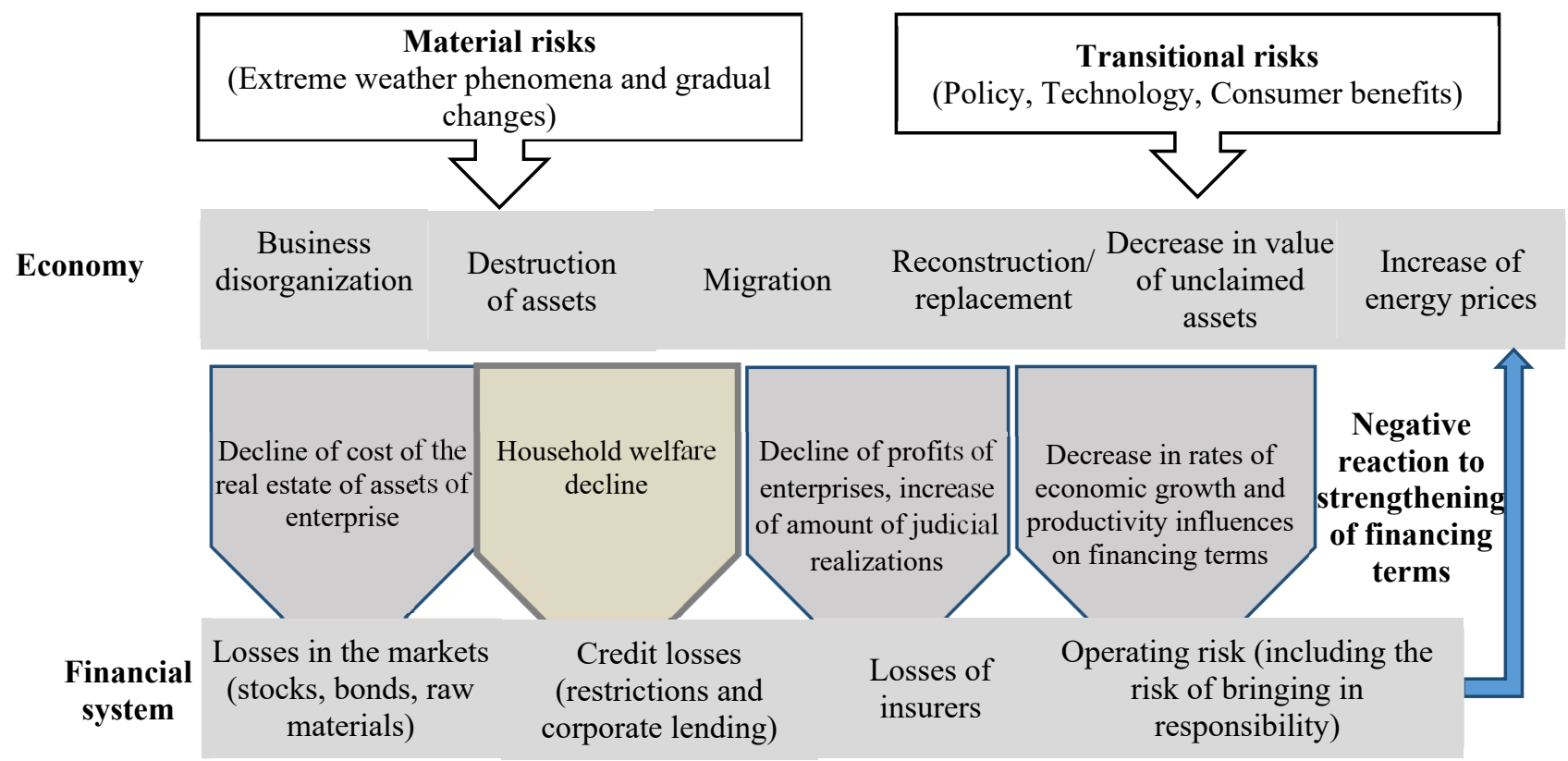

Fig. 1. Material and transitional risks for global economy from climate changes.

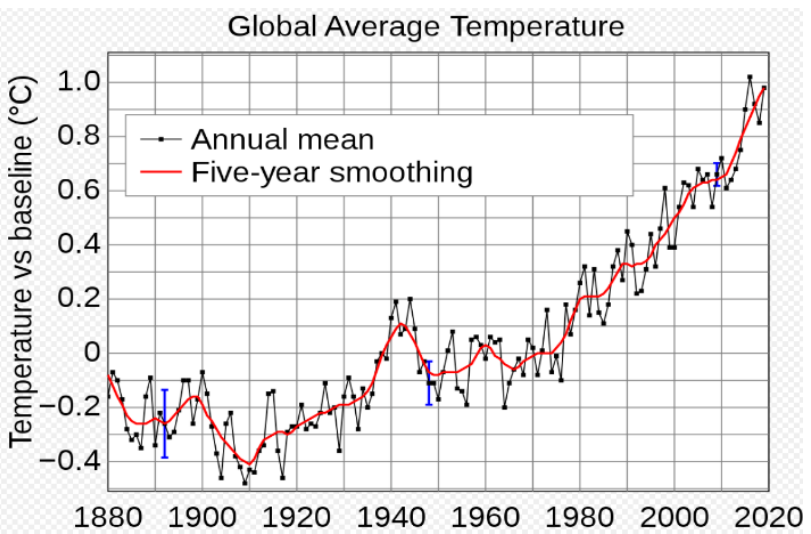

Fig. 2. Changes of global average temperature over the land and the ocean during 1880-2015, concerning average temperature for 1951-1980. Note: By black line is designated average annual and by red - moving average in 5 years. Source: Institute of comic researches of Goddard in NASA [14].

Since 2016 the highest economic losses were recorded from natural disasters during the last five years in the world: and the general losses in the economy made $\$ 175$ billion; the insured losses exceeded $\$ 54$ billion (against $\$ 94$ billion and $\$ 38$ billion respectively in 2015). As we see, both graphics correlate among themselves from what we can make a conclusion - an increase in global average temperature over the land and the ocean is one of the reasons for the growth of the number of natural disasters, since the 90th years of the last century.

According to forecasts, by 2030 economic losses will exceed $3 \%$ of global GDP (depending on the level of development of the country, this indicator can be from
According to the world meteorological organization, average temperatures of the periods of five (2015-2019) and ten years (2010-2019) are highest during the entire period of observation (fig. 2).

\section{Transitional risks}

(Policy, Technology, Consumer benefits)

replacement
of unclaimed
assets

Increase of 


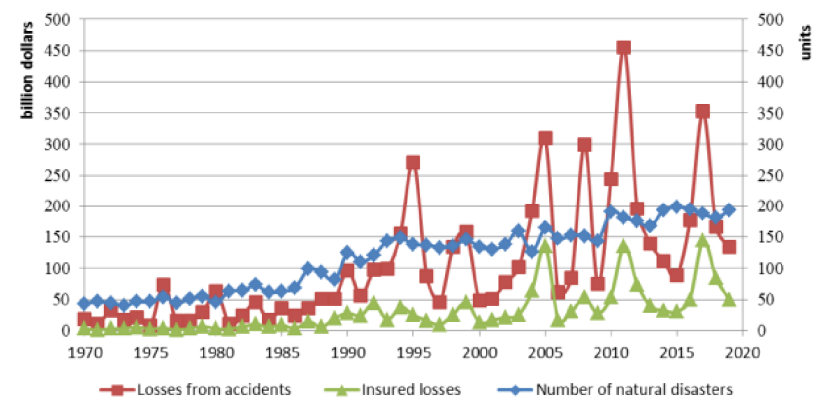

Fig. 3. Dynamics of the number of natural disasters, losses from accidents and the insured losses during 1970-2020. In the world, one billion US dollars. Source: powered by [16].

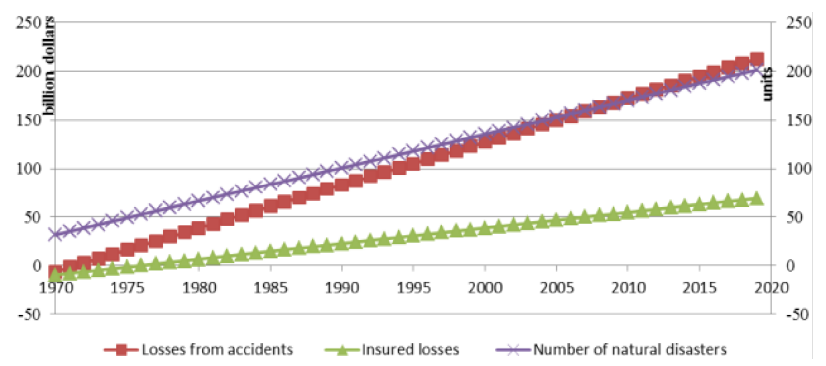

Fig. 4. Trends of number of accidents of natural-science character, losses from accidents and insurance losses. Source: powered by [10].

Losses from accidents correlate with the number of accidents. From figure 4 it is visible that the gap between losses from accidents and losses that were insured and, respectively, were compensated by insurers increases. Insurance losses lag behind losses of accidents that indicates lack of attention of participants of the insurance relations to possible mechanisms of protection against the losses caused by such risks. Insurance companies undertake carefully risks as the probability of their ruin grows.

Thus, climate change is a serious threat for the world economy that forces insurance companies to refuse traditional approaches to risk assessment and also to raise rates because of the inability to estimate the probability of natural disasters. The standard approaches to risk assessment that are used in insurance, are based on the analysis of historical data, but modern practice demonstrates that nowadays they are insufficient, and risks connected to natural disasters, more often even not accepted on insurance by insurers. There is an increasing number of non-insurance risks in the world, and the main reasons for such state of affairs are the unpredictability of the effects of global warming, an intensification of natural disasters and raisings of global ocean level.

The role of insurance companies in opposition to climate changes is carried out in the directions:

- compensation of consequences of natural phenomena; - participation in the organization and financing of preventive actions; financing of economy by long-term investment (for example, the Swiss Re undertook the obligation to transfer the investment portfolio to clean zero emission of greenhouse gases to 2050 and entered TOP-5 of brands that got approval from NGOs in 2018 because of climatic actions);
- stimulation of insurers to the reduction of emissions of carbon dioxide;

- modification in insurance programs for the purpose of reduction of emissions of greenhouse gases; investments into renewable energy sources.

However, the development of methods of measurement of economic losses from climate change is not finished yet. Insurers have an opportunity to estimate short-term losses from change of weather characteristics, more frequent and more and more destructive natural disasters, but the main part of potential costs does not fit into a framework of the standard economic analysis. Scales of economic consequences of climate change, most likely, will grow, though not smoothly. What is especially important for future generations, that degree of damage will depend on what measures of policy will be adopted for protection against consequences of climatic changes today.

Such trends transform also the role of global insurers and reinsurers in the conditions of climate change changes. The considerable sums are allocated to the development of decisions for overcoming the growing risks [17], connected to climate change and for reduction of a gap in insurance. The saved-up statistical data constructed by insurers of the model of spontaneous accidents facilitate risk assessment. Besides, insurers carry out activity and at directly informing and increase in awareness of business and communities on risks for the purpose of strengthening their stability. Using the latest technologies, insurers can and improve the opportunities of modeling of risks and develop new decisions for primary and secondary dangers to help to reduce uninsured risk of an accident. Restriction of global warming requires participation of "all society". Cooperation between insurance companies, reinsurance, and the public sector can make the world steadier, more compatible with life, growth, and development. The influence of the effects of climate change becomes more and more noticeable and significant, but at the same time, it opens great opportunities. Thanks to cooperation more practical and reliable models of insurance can be introduced and realized.

Insurance companies around the world not only make changes to the programs for the reduction of emissions of greenhouse gases but stimulate insurers to reduce emissions of carbon dioxide and also are engaged in investment into renewable energy sources. Insurers support the implementation of new technologies, insuring risks of introduction of innovations, related to renewable energy and other areas.

The national governments, regulators, and businesses have to fight together effectively against climate change and accelerate the transition of a society to renewable economy, seeking for use of reduction in carbon technologies.

Insurers and reinsurers take part in the fight against climate change in such directions: inform society on risks of global warming, compensate consequences of natural disasters, participate in the organization of precautionary actions and finance economy by long-term investment.

Insurance is only one of the available funding mechanisms for natural disasters. However, this process 
is necessary to consider in a wider fiscal framework which also includes international aid, reduction of debt, use of other financial securities, the formation of reserves of accidents and government budgets. Besides, insurance and other funding mechanisms for risk of natural disasters are only a part of the decision, they need to be integrated into other actions concerning stability and adaptation as a part of the complex strategy of adaptation to climate change. Therefore insurance products are connected to climate risks, and can act on micro, meso- and macrolevels.

1. Micro-insurance is the direct insurance of individuals or insurers of small businesses. However, more often microinsurance means development micro products for insurance of the most vulnerable persons in the countries with low-income level; The Parallel with the concept of microfinance.

2. Meso-insurance refers to those situations in which the insured is not an individual, but rather an aggregation of individuals under a collective body. For example, the insured might be an organization that supports a collective of farmers within an area. This meso-level organization buys an insurance product designed to cover the collective of individuals; the individuals themselves are indirect beneficiaries of financial protection. They will receive payments from the meso-level organization, based on any claims paid to the organization through insurance.

3. In macro-insurance the insurer, as a rule, is the state subject, such as government which pays an insurance for ensuring payments in case of national accidents, such as a flood or a tropical storm. Payment for the state product can be used for various purposes on behalf of the population of this country. For example, payments can be used for the public services so that they could support further the help owing to accidents.

\section{Conclusion}

Climate change carries out notable consequences for the sector of insurance and reinsurance. In the world where the climate risk grows, financial protection becomes even more important even if the costs of it also grow. Thus, insurance products, services in reinsurance and securities - all these are examples of financial shock-absorbers concerning the risk of climate change, but at the same time, their use can encourage changes in the behavior of society for the purpose of slowing down of negative changes of global climate.

A search of the balance between ensuring the availability of services and management of financial stability can become tougher for insurers if extraordinary weather conditions continue to amplify. Adapting insurance management to climatic anomalies, insurers have to concentrate on:

- strengthening of risk assessment, related to climate, at the same time, using long-term measures for reduction and mitigation of such impacts;

- use of complete approach to risk management, related to climate, integrating them as a part of the efforts on risk management of the company;
- introduction of actions, in order to show better the readiness for climate changes to regulators, analysts, and customers;

- development of innovative solutions by insurers, related to climate changes.

These measures can help insurance companies and regulators to create more equal conditions and a stable market for all interested parties.

Key conclusions of research can be presented by such theses:

1. Climate change enhances economic risks for insurers.

2. Large insurance companies develop new approaches to the assessment of risks of the approach of extreme weather conditions and make corresponding changes to insurance contracts.

3. New services in the insurance market are intended to support environmentally friendly technologies; however, insurance companies pay close attention to problems of adaptation to the risks caused by global warming.

Thus, traditional understanding of a role of the insurance industry in fight against consequences global heating changes. There is a transformation of understanding a role of insurance companies - transition from traditional insurance mechanisms to realization of preventive function of insurance, collecting and providing data as for changes of temperatures, quantity and force of natural disasters, informing society about threats of carbon use, and restriction of insurance of productions, which use fossil fuels.

\section{References}

1. Ye. Tykhomyrova, Climate change as a composition of international security programs. Visnyk of the Lviv University. Series International Relations. (2018). doi:10.30970/vir.2018.44.0.9466

2. M. Mobjork, T. Gustafsson, H. Sonnsjo, S. van Baalen, L.M. Dellmuth, N. Bremberg, Climaterelated security risks: towards an integrated approach (SIPRI, 2016), https://www.sipri.org/publications/2016/climaterelated-security-risks. Accessed 16 Feb 2020

3. New report on climate change: urgent and decisive action required, otherwise the worst cannot be avoided (2019),

https://news.un.org/ru/story/2019/09/1363352. Accessed 15 Feb 2020

4. UN Secretary-General: "Fossil fuels must stay forever where it should be - underground" (2019), https://news.un.org/ru/story/2019/12/1368241. Accessed 15 Feb 2020

5. The Global Risk Report 2020 (WEF, 2020), https://www.weforum.org/reports/the-global-risksreport-2020. Accessed 16 Feb 2020

6. Climate crisis can hit half of world GDP - WEF report (2020), https://mind.ua/news/. Accessed 14 Feb 2020

7. National Standards of Ukraine 3992-2000 Climatology. Terms and definitions of basic concepts (2000), 
http://online.budstandart.com/ua/catalog/docpage.html?id_doc $=69183$. Accessed 13 Feb 2020

8. N. Prots, Climate security: the essence and need for financial security. Economic Journal of Lesya Ukrainka Eastern European National University (2018). doi:10.29038/2411-4014-2018-01-142-148

9. O. Horyn, New climate era: global warming may have both negative and positive impacts for Ukraine (2012), http://tyzhden.ua/Society/55859. Accessed $16 \mathrm{Feb} 2020$

10. A. Kokorin, Climate change: review of the fifth assessment report IPCC (WWF, 2014), https://www.twirpx.com/file/1661391/. Accessed 13 Feb 2020

11. Yu. Kostiuchenko, Climate change is a threat to national security (2013), https://www.radiosvoboda.org/a/25139156.html. Accessed 13 Feb 2020

12. S. Turianytsia, Yu. Andrashko, V.Petrov, M.Sakal, Dynamics of the Lyme disease situation in Zacarpathia (Clinical immunology. Allergology. Infectology, 2012), http://kiai.com.ua/article/719.html. Accessed 14 Feb 2020

13. Insurance for climate adaptation: opportunities and limitations (Rotterdam and Washington, 2019), https://www.insuresilience.org/wpcontent/uploads/2019/08/Insurance-for-climateadaptation_Opportunities-and-Limitations_Web.pdf. Accessed 16 Feb 2020

14. GISS Surface Temperature Analysis (NASA Goddard Institute for Space Studies, 2019), http://data.giss.nasa.gov/gistemp/. Accessed 16 Feb 2020

15. Natural catastrophes and man-made disasters in 2018: "secondary" perils on the frontline (Sigma, 2019), https://www.swissre.com/. Accessed 12 Feb 2020

16. L. Bevere, T. Holzheu, C. Wong, Global catastrophes caused USD 56 billion insured losses in 2019, estimates Swiss Re Institute (Swiss Re, 2019), https://www.swissre.com/media/news-releases/nr20191219-global-catastrophes-estimate.html. Accessed 16 Feb 2020

17. L. Bevere, Secondary natural catastrophe risks on the front line (Swiss Re, 2019), https://www.swissre.com/institute/research/sigmaresearch/sigma-2019-02.html. Accessed 15 Feb 2020 